\title{
Advancing Wireless Devices-A Step Closer towards Cancer
}

\author{
Bhumika Bhatt ${ }^{1}$ and Har Ashish Jindal ${ }^{2 *}$ \\ ${ }^{1}$ Department of Community Medicine,K.D. Medical College Hospital and Research Center, India \\ ${ }^{2}$ Department of Community Medicine, School of Public Health, India
}

Submission: June 17, 2018; Published: July 05, 2018

"Correspondence Address: Har Ashish Jindal, Senior Resident, Department of Community Medicine PGIMER, Chandigarh, India, Email: harry8723@gmail.com

\section{Abstract}

Wireless devices use several types of radiations like microwave, infra-red waves, radio waves etc. Frequency of such wireless devices range from $30 \mathrm{khz}$ to $300 \mathrm{GHz}$. Main concern regarding use of mobile phones are whether they can cause cancers. Radiofrequency exposure limits for mobile phone users are given in terms of Specific Absorption Rate (SAR) which help limit the exposure. Several studies that will provide more information are under way and have already been conducted. The research demands low hazard technology and preventive ways to reduce health hazards posed by wireless technology. Prevention and judicious use is the key to protection from cancer risk.

Keywords: Wireless;Cancer; Technology; Mobile; Phone

\section{Introduction}

Wireless devices are an integral part of our daily life and their use has been increasing ever since their advent. Wireless technology came into existence in 1880 by Graham Bell and Sumner Tainted when the photo phone was invented[1]. These devices need no wires to be run through buildings, over ground or underground; are portable, feasible, easier to use convey information quickly. They use air as a medium to send data through electromagnetic radiations. Human body does not feel such radiations, but these can penetrate through the body and affect the genetic material present in the cells. The genetic material is DNA which is most sensitive to ionizing radiation.

These devices use several types of radiations like microwave, infra-red waves, radio waves etc. Frequency of such wireless devices range from $30 \mathrm{khz}$ to $300 \mathrm{GHz}$. There are several wireless gadgets such as Wireless modem/routers, Cell phone tower, cell/ mobile phone, bluetooth devices and audio player. Notion has been that radiations may cause many problems such as, decrease sperm count, abortions, brain cancers, hearing issues,malformations, Parkinson's disease, Alzheimer's disease [2].

According to WHO fact sheet in 2014 , there is an estimated 6.9 billion subscriptions globally. There are some parts of the world where mobile phones are most effective or the only phones available[3].In India the Telecom Sector witnessed substantial growth in the number of subscribers during the year
2016-17 also. At the end of the financial year, the subscriber base was 1194.58 million out of which 1170.18 million were wireless subscribers. During the year, wireless subscriber base recorded an increase of 136.55 million, while the overall teledensity increased from 83.6 to 92.98[4]. Internet penetration in India is no more only limited in urban area, approximately $35 \%$ of internet users are from rural India. At the end of December 2014 , internet subscribers in rural area was 92.18 million with tele- density of 10.66 and internet subscribers in urban area was 175.21 million with tele-density of 45.33 [5].

\section{Discussion}

\section{Use of Wireless Devices and Risk of Cancers}

Cell phones mechanics through signals transmission by cell towers using Radio Frequency (RF) waves. RF waves are a form of non-ionizing radiation. Although these don't have enough energy to cause cancer by directly damaging the DNA inside cells but multiple factors which can affect the amount of RF energy to which a person is exposed are amount of time the person is on the phone, whether the person is using the speaker mode, distance and path to the nearest cell phone tower, amount of cell phone traffic in the area at the time and model of phone being used[6].

Main concern regarding use of mobile phones are whether they can cause cancers e.g. brain tumors, skin cancers or testicular cancers. According to American Cancer Society two 


\section{Cancer Therapy \& Oncology International Journal}

types of studies are conducted to find association between mobile phone usage and risk of cancer. They are lab studies (conducted in animals) and studies conducted in people. In most cases neither type of study provides enough evidence on its own to show if something causes cancer in people, so researchers usually look at both lab-based and human studies. Most studies done in the lab have supported the idea that RF waves do not cause DNA damage[6].

The US National Toxicology Program (NTP) conducted a study that exposed large groups of lab rats and mice to RF energy over their entire bodies for about 9 hours a day, starting before birth and continuing for up to 2 years in a draft report of the results (issued in February 2018), the study found an increased risk of tumors called malignant schwannomas of the heart in male rats. But some aspects of this study make it hard to know just how well these results might be applied to cell phone use in people. The doses of radiation in the study were also generally higher than those used in cell phones, the animals' entire bodies were exposed, and the amount of time they were exposed was longer than most people typically spend on the phone each day[6]. There have been plenty of epidemiologic studies in humans to investigate the possibility of a relationship between cell phone use and the risk of malignant (cancerous) brain tumors, as well as benign (noncancerous) tumors[7].

Studies done in humans has mixed results. Epidemiologic studies were: Interphone, a case-control study; the Danish Study, a cohort study; and the Million Women Study another cohort study[8]. The Interphone study was a case-control study conducted in thirteen countries which looked at cell phone use among more than 5,000 participantswho developed brain tumors (gliomas or meningiomas) and a similar group of people without tumors. Overall, the study found no link between brain tumor risk and the frequency of calls, longer call time, or cell phone use for ten or more years[6].

The cohort study was conducted in Denmark, linked billing information from more than 358,000 cell phone userswith brain tumour incidence data. No association was observed between cell phone use and the incidence of glioma, meningioma, or acoustic neuroma, even among people who had been cell phone subscribers for 13 or more year[9-11].The United Kingdom cohort study million-woman study found cell phone use was not associated with an increased risk of glioma, meningioma, or non-central nervous system tumours. However, the original published findings found an increased risk of acoustic neuroma [12], this association disappeared after additional follow-up of the cohort [13].

In a metanalysis conducted by Prasad and Kathuria et al. [14] twenty-two case control studies were included for systematic review. Meta-analysis of fourteen case-control studies showed practically no increase in risk of brain tumour [OR 1.03 (95\% CI 0.92-1.14)]. Mobile phone usage of more than 10 years or longer (or $>1640 \mathrm{~h}$ ), showed a significant 1.33 times increase in risk. There were are two NCI-sponsored case-control studies, each conducted in multiple U.S. academic medical centers or hospitals between Neither study showed a relationship between cell phone use and the risk of glioma, meningioma, or acoustic neuroma[15,16].

The CERENAT study, was a case-control study conducted in multiple areas in France from 2004 to 2006 using data collected in face-to-face interviews using standardized questionnaires (20). This study also found no association between usage of mobile phones and risk of cancers[17].Other than that, investigators have also conducted analyses of incidence trends to determine whether the incidence of brain or other cancers has changed during the time that cell phone use increased dramatically. An analysis of data from NCI's Surveillance, Epidemiology, and End Results (SEER) Program evaluated trends in cancer incidence in the United States. This analysis revealed that there was not anincrease in the incidence of brain or other central nervous system cancers between 1992 and 2006, despite the dramatic increase in cell phone use in this country during that time [18].

A regress analysis of incidence data from Denmark, Finland, Norway, and Sweden for the period 1974-2008 similarly revealed no increase in age-adjusted incidence of brain tumours [19].There are special concerns regarding risk of developing cancers in children and mobile phone usage. Thus far, the data from studies in children with cancer do not support this theory. The first published analysiscalled CEFALO, which was a case control study in Denmark, Sweden, Norway, and Switzerland. Researchers did not find any significant resultsbetween cell phone use and brain tumour risk either by time since initiation of use, amount of use, or by the location of the tumour[20].

In 2011, the International Agency for Research on Cancer Exit Disclaimer (IARC), a component of the World Health Organization, appointed an expert Working Group to review all available evidence on the use of cell phones. Although, Working Group hadclassified cell phone use as "possibly carcinogenic to humans," based upon the scarce evidence from human studies, less evidence from studies of radiofrequency energy and cancer in rodents, and inconsistent evidence from mechanistic studies[21].

Some studies had shown that the frequency range from $40 \mathrm{MHz}$ to $6 \mathrm{GHz}$ has ability to deeply penetrate inside tissues due to irregular molecular motion, this effects on DNA. The electromagnetic field exposure may dramatically increasethe occurrence of cancer and brain tumor. Use of cellphone near the head and neck area maypenetrate inside human brain as deep as 4 to $6 \mathrm{~cm}$. This action of radiations affects the hippocampus and pineal gland by decreasing their protein kinase $\mathrm{C}$ and melatonin activity. A study by Starkey shows that if the cell phone is being used in a very close contact with the brain, for more than one hour per day continuously for 10 years or above will increase the 
risk of brain tumor[22] Study by Emami et al. [23] had showed that microwave frequencies are more effective to the brains of children than the adult because cells of children are still dividing as well as they have a thin skull and brain. Simko et al. [24]in a study had told that radiations of cell phone increases risk of brain tumor because of the damage to blood brain barriers due to these radiations.

Majority of studies have shown no association between use of wireless devices and risk of cancer, but some have proven otherwise. Reasons for these discrepancies may be recall bias, inaccurate reporting, Morbidity and mortality among study participants who have brain cancer, Participation bias, which can happen when people who are diagnosed with brain tumors are more likely than healthy people (known as controls) to enroll in a research study and changing technologies[8].

\section{Research in process}

The COSMOS Exit Disclaimer, large prospective cohort study using cell phone use and long-term health effects in 2010 enrolled approximately 290,000 cell phone users aged 18 years or older to date and will follow them for 20 to 30 years. The barrier is to continue following the participants for a range of health effects over many decades[8].

Several studies that will provide more information are under way. Researchers from the Centre for Research in Environmental Epidemiology in Spain are conducting another international case-control study-Mobi-Kids that will include 2000 young people (aged 10-24 years) with newly diagnosed brain tumors and 4000 healthy young people. This study help learns more about risk factors for childhood brain tumors. Results are expected in 2018[8].

\section{Prevention}

The Food and drug Authority of America has suggested some steps that concerned cell phone users can take to reduce their exposure to radiofrequency energy. These are reserving the use of cell phones for shorter conversations or for times when a landline phone is not available. The use of hands-free gadgets, such as wired headsets, which keep distance between the phone and the head of the user.Wireless devices should not be treated as devices for leisure and should be designednot to appeal to young children [25].

People should not place cellphones direct contact with skin especially bras, inside any type of head covering and try andcell phone calls to an absolute minimum, especially where children are involved. Wireless connections should be switched off if not usingphone. The bedrooms should be safe havens, free of electronic devices. all electronic equipment ahold be turned off for a more restful, healthier sleep. Remove all forms of wireless, including cordless phones and Wi-Fi. Replace these with a hardwired computer and a corded phone. [26].
Laws regarding radiofrequency exposure limits for mobile phone users are given in terms of Specific Absorption Rate (SAR) - the rate of radiofrequency energy absorption per unit mass of the body. Apparently, there are only two international bodies who have developed exposure guidelines for workers and for the public. $[27,28]$.

\section{Conclusion}

As the era advances towards technology and wireless communication,it does pose some risk towards cancer. Prevention and judicious use is the key to protection from such risk. Use of SAR while buying electronic devices also is very helpful. Although with mixed results of conducted studies, further research is warranted to help us reorient ourselves to use the technology in a safer way Today the research demands low hazard technologyand preventive ways to reduce health hazards posed by wireless technology

\section{Acknowledgement}

None.

\section{Conflict ofInterest}

None.

\section{References}

1. Carson MK (2007) Alexander Graham Bell: Giving voice to the world Sterling Publishing Company Inc., New York, USA.

2. Larik RSA, Mallah GA, Talpur MMA, Suhag AK, Larik FA (2016) Effects of Wireless Devices on Human Body. J Comput Sci Syst Biol 9: 119-124.

3. World Health Organization (2014) Electromagnetic fields and public health: mobile phones. WHO, Geneva, Switzerland.

4. TRAI, GOI (2017) Overview of telecom and broadcasting sectors, New Delhi, India.

5. Growth of Internet Users in India and its Impact on our life (2018) Open Government Data Platform India Blog.

6. Cellular Phones (2018) Cancer org. American Cancer Society, USA.

7. Ahlbom A, Green A, Kheifets L, Savitz D, Swerdlow A (2005) Epidemiology of Radiofrequency Exposure: Ahlbom et al. Respond. Environmental Health Perspect 113(3): A151-A152.

8. Cell Phones and Cancer Risk (2018) National Cancer Institute, USA.

9. Johansen C, Boice J Jr, McLaughlin J, Olsen J (2001) Cellular telephones and cancer: a nationwide cohort study in Denmark. Journal of the National Cancer Institute 93(3): 203-207.

10. Schüz J, Jacobsen R, Olsen JH, Boice JD Jr, McLaughlin JK, et al. (2006) Cellular telephone use and cancer risk: update of a nationwide Danish cohort. J Natl Cancer Inst 98(23): 1707-1713.

11. Frei P, Poulsen AH, Johansen C, et al. (2011) Use of mobile phones and risk of brain tumours: update of Danish cohort study. BMJ 343: d6387.

12. Benson VS, Pirie K, Schüz J, Reeves GK, Beral V, et al. (2013) Mobile phone use and risk of brain neoplasms and other cancers: Prospective study. Int J Epidemiol 42(3): 792-802.

13. Benson VS, Pirie K, Schüz J, , Reeves GK, Beral V, et al. (2014) Authors' response to: the case of acoustic neuroma: comment on mobile phone use and risk of brain neoplasms and other cancers. Int J Epidemiol 43(1): 275 . 


\section{Cancer Therapy \& Oncology International Journal}

14.Prasad M, Kathuria P, Nair P, Kumar A, Prasad K (2017) Mobile phone use and risk of brain tumours: a systematic review of association between study quality, source of funding, and research outcomes. Neurol Sci 38(5): 797-810.

15. Muscat JE, Malkin MG, Thompson S, Shore RE, Stellman SD, et al. (2000). Handheld cellular telephone use and risk of brain cancer. JAMA 284(23): 3001-3007.

16. Inskip PD, Tarone RE, Hatch EE, Timothy C Wilcosky, William R Shapiro et al. (2001) Cellular-telephone use and brain tumors. New England Journal of Medicine 344(2): 79-86.

17. Coureau G, Bouvier G, Lebailly P, Fabbro-Peray P, Gruber A, et al. (2014) Mobile phone use and brain tumours in the CERENAT casecontrol study. Occup Environ Med 71(7): 514-522.

18. Inskip PD, Hoover RN, Devesa SS (2010) Brain cancer incidence trends in relation to cellular telephone use in the United States. NeuroOncology 12(11): 1147-1151.

19. Deltour I, Johansen C, Auvinen A, Feychting M, Klaeboe L, et al. Time trends in brain tumor incidence rates in Denmark, Finland, Norway, and Sweden, 1974-2003 J Natl Cancer Inst 101(24): 1721-1724.

20. Aydin D, Feychting M, Schüz J, Tynes T, Andersen TV, et al. (2011) Mobile phone use and brain tumors in children and adolescents: a multicenter case-control study. J Natl Cancer Inst 103(16): 1264-1276.

21. International Agency for Research on Cancer (2013) Non-ionizing Radiation, Part 2: Radiofrequency Electromagnetic Fields Exit
Disclaimer. IARC monographs on the evaluation of carcinogenic risks to humans, Volume 102, IARC, Lyon, France.

22. Starkey S (2011) Discussing mobile phone safety with young people. Brit J Sch Nurs 6: 434-438.

23. Emami Z, Turan AG, Razavi GSE (2012) Study on the relationship between electromagnetic waves of cell phone and the prevalence of the Glioma and Meningioma.

24.Simko M (2007) Cell type specific redox status is responsible for diverse electromagnetic field effects. Curr Med Chem 14(10): 11411152.

25. US Food and Drug Administration (2009) Radiation-Emitting Products: Reducing Exposure: Handsfree. Maryland, USA.

26. Gwyneth Paltrow warns of the dangers of cell phone use and WiFi radiation (2016) Natural Health 365.

27. International Commission on Non-Ionizing Radiation Protection (ICNIRP) (2009) Statement on the Guidelines for limiting exposure to time-varying electric, magnetic and electromagnetic fields (up to 300 GHz) $97(3): 257-258$.

28. Institute of Electrical and Electronics Engineers (IEEE) (2005) IEEE standard for safety levels with respect to human exposure to radio frequency electromagnetic fields, $3 \mathrm{kHz}$ to $300 \mathrm{GHz}$. IEEE Std C95.1, USA.

\section{Your next submission with Juniper Publishers} will reach you the below assets

- Quality Editorial service

- Swift Peer Review

- Reprints availability

- E-prints Service

- Manuscript Podcast for convenient understanding

- Global attainment for your research

- Manuscript accessibility in different formats

(Pdf, E-pub, Full Text, Audio)

- Unceasing customer service

Track the below URL for one-step submission https://juniperpublishers.com/online-submission.php 